\title{
Invasive alien plant species, fragmentation and scale effects on urban forest community composition in Durban, South Africa
}

\author{
Lindani Z. Mavimbela* (D, Erwin J. J. Sieben and Şerban Procheş
}

\begin{abstract}
Background: Urban forests are under increased pressure from invasion by exotic (alien) species. The vegetation present in the matrix of urban sites is a rich source of alien invasive propagules, which increases the risk of alien invasion in forests within an urban space, leading to a decline in indigenous species. Therefore, determining the distribution patterns of native and exotic species as influenced by environmental factors can assist in quantifying the impact of exotic species at broad scales based on responses on a finer scale. Quantifying the effects of multiple environmental factors on the distribution patterns of both indigenous and alien species in the ecosystem may help in prescribing suitable management efforts.

Methods: Fifteen forest patches were sampled in the eThekwini (Durban) Municipality and data collected from 74 $100-\mathrm{m}^{2}$ plots with different degrees of invasion. Indigenous and alien species of trees, shrubs and climbers occurring in ten and more plots were considered for analysis and the CANOCO 5.1 package was used to run various constrained ordination analyses. Variation partitioning analysis was used to assess the impact of environmental variables at different spatial scales, namely the plot and patch scales.
\end{abstract}

Results: Canopy gaps are the major controlling factor for invasive alien plants (IAPs) occurrence at fine scale. At patch level, residential and industry areas outside the boundaries (buffer area) of forest patches have a high influence on the distribution of IAPs. Communities dominated by the invasive Chromolaena odorata (L.) R.M. King are most common on the lowland coastal forests while communities dominated by either Litsea glutinosa (Lour.) C.B.Rob. or Cardiospermum grandiflorum Sw. can prevail in both lowland coastal and scarp forests.

Conclusions: Canopy gaps in lowland forests can facilitate the transition of native forests to novel communities containing a variety of alien plant species. Communities of shrub, climber and tree IAPs occur in lowland coastal forests while climber and tree IAPs dominate the high-elevation scarp forests. The resilience shown by some native species to the tree, shrub and climber IAPs by remaining when IAPs establish makes these species very suitable for restoration projects. Forest patches surrounded by a high incidence of residential and industrial areas in the buffer matrix are likely to have a high diversity of IAPs. Larger patch size and high connectivity to nearby native forests are key in reducing invasion by IAPS.

Keywords: Species community, Patch connectivity index, Invasive species

\footnotetext{
*Correspondence: vimbi28@gmail.com

School of Agricultural, Earth and Environmental Sciences, University of

KwaZulu-Natal, University Road Westville, Private Bag X 54001, Durban 4000,

South Africa
} 


\section{Background}

Urbanisation generally has negative impacts on ecosystems, mainly because of habitat loss (Boon et al. 2016; Lehosmaa et al. 2017; Nor et al. 2017; Galic et al. 2018). Urban expansion is primarily driven by population growth (Ersoy 2016) and the consequent increase in demand for services (EPCPD 2016; Lehosmaa et al. 2017). The reduction of vegetation in urban areas and soil manipulation due to anthropogenic development/expansion lead to the overall reduction of urban green space (Threlfall et al. 2016). Green spaces in urban areas support many plant species, both native and non-native. Some of the native species can be endemic or endangered and should be protected due to the vulnerability to extinction in their communities (Lepczyk et al. 2017). The overall diversity of native species is determined by the size, quantity and quality of urban green spaces. Green space networks in cities are recognised around the globe to be fundamental for urban ecosystem functioning (Boon et al. 2016) and for the health and wellbeing of residents through food provision and pollution removal (Threlfall et al. 2016; Nor et al. 2017). From a spatial-ecology perspective, the reduction of green spaces does not only lead to reduced sizes of forest patches. The reduction in green space causes an increase in the ratio of the area of edge habitats to total patch size (Vidra 2004; Bergsten et al. 2013). Forest centres having closed canopies act as physical barriers to dispersal pathways, and the prevailing light and moisture conditions act as environmental barriers to the establishment of alien plants. Forest edges have lower canopy cover and are closer to transportation corridors and thus they may have weaker physical and environmental barriers to invasion (Hansen and Clevenger 2005). Forest edges create a favourable micro-climate for establishment of invasive alien plants (IAPs) (Vidra 2004; Bierwagen 2005; Bergsten et al. 2013). This implies that forest patches that are highly fragmented can have altered successional processes, whereby early successional exotic species alter and increase the risk of decline in native species (Singer et al. 2016). The Durban Metropolitan Open Space System (D'MOSS) occurs along a variety of habitat types and includes areas of high biodiversity value linked to form an ecologically viable network. The network of areas (ca. 75,000 ha; one third of the municipality) has a high biodiversity value and has been under municipal management for over three decades (Boon et al. 2016; EPCPD 2016).

Physical features of urban areas such as buildings, large impermeable concrete surfaces, pollution, high human population and traffic density are known for promoting the establishment of alien plant species. These physical features may alter resource availability, such as increased light where trees are cut and high soil moisture occurring along drainage channels or paths (Grunewald et al. 2018). More often, plant communities with high resource availability allow for homogenous growth of early successional alien plants or a high diversity of invasive alien plant species (IAPs) (Muster et al. 2014). In this study, the acronym 'IAPs' refers to naturalised plants that regenerate in large numbers in distant locations from the location where parent plants were introduced (Richardson et al. 2000). These communities normally have high densities of IAP propagules (Heinrichs and Pauchard 2015). Plant communities with a high density of propagules normally exert propagule pressure to nearby forest reserves (Heinrichs and Pauchard 2015; Padayachee et al. 2017). Landscape connectivity is used to describe the structural and functional continuity of ecosystems (Ziółkowska et al. 2014; Nor et al. 2017) from landscape to regional scale (LaPoint et al. 2015). Structural connectivity is measured by landscape metrics such as patch size, isolation and the identification of linear features that may act as conduits or barriers to IAP movement (LaPoint et al. 2015). This means that connectivity is a vital element to maintain gene flow and to facilitate species movement, distribution, dispersal and recolonisation (LaPoint et al. 2015; Naicker et al. 2016; Nor et al. 2017). Consequently, it may also influence the success of establishment and spread of IAPs (Vidra 2004; Bierwagen 2005; Procheş et al. 2005).

In forest communities, the invasion levels by exotic species depend on the integrity of the canopy cover whereby forests with many and relatively large canopy gaps are readily invaded. This is because invasive species establish and grow rapidly in large canopy gaps and along forest margins (Geldenhuys 2004). Some forest sites experiencing branch or tree falls that are small in nature have shown to be sufficient to allow low light demanding tree invasive species to grow to the canopy (van Wyk et al. 1996). Canopy gaps facilitate the coexistence of large numbers of species because they remove barriers of dispersal and recruitment while advancing the growth of early-successional species which are suppressed under the forest canopy (Lawes et al. 2004). Forest edges that are dense and forest canopies that are closed often create physical barriers for light demanding IAPs and limit their dispersal pathways (Hansen and Clevenger 2005). Late-successional species are lost through disturbance regimes that cause canopy gaps, leading to the establishment of light-demanding pioneer species which are adapted to colonising new disturbed sites (Lawes et al. 2004). Furthermore, IAPs are likely to become dominant near forest paths because of the physical disturbance of the soil and vegetation which increases light conditions and this favours the growth of IAPs (Hansen and Clevenger 2005).

The functional types of IAPs namely trees, shrubs and climbers are considered to have a negative impact on 
forest integrity, as illustrated by several species established in coastal KwaZulu-Natal (Geldenhuys 2013). The tree IAP Litsea glutinosa (Lour.) C.B.Rob. establishes vigorously in humid areas of sub-tropical forests. This light-demanding plant takes advantage of small canopy gaps in the forest, and its vegetative reproduction by root-suckering makes it an aggressive invader that poses a threat to biodiversity loss under canopy (Jacq et al. 2005). Similarly, Melia azedarach L. invades urban open space, wasteland and riparian zones (Henderson 2001). When the species undergoes physiological damage, it can reproduce by vegetative means through stump and root sprouts for its persistence in the environment (Tourn et al. 1999). The shrub Chromolaena odorata (L.) R.M. King is restricted to frost-free areas and displays great plasticity in terms of growth form and in terms of the vegetation types it invades (Zachariades et al. 2002). The shrub Lantana camara L. grows aggressively and causes ecological destruction through loss of species diversity and more so due to its ability to dominate the understorey (Totland et al. 2005). Another evergreen perennial branched shrub (Olckers 1999), which is aggressive, extremely resilient, invades riparian, forest, grass and agricultural land is Solanum mauritianum Scop. (Witkowski and Garner 2008; Peerbhay et al. 2016). The climber Cardiospermum grandiflorum Sw. grows vigorously in damp conditions preferably along forest margins and watercourses of the subtropics (Simelane et al. 2011), climbing to heights of $6 \mathrm{~m}$ up to $10 \mathrm{~m}$ (Henderson 2001; Krings and Braham 2005). Once the invader is well established, it forms a smothering curtain which outcompete indigenous species for sunlight (Simelane et al. 2011). Another climber, Ipomoea purpurea (L.) Roth, grows vigorously twining above the vegetation around them for light (Defelice 2001). Furthermore, the vine is adapted to low light intensities found in the forest understorey (Defelice 2001). The plastic physiological and morphological traits of some IAPs allow for the efficient use of available resources for fast growth such as soil moisture, nutrients and light; hence, they can outperform less plastic native species (Leishman et al. 2007; Funk 2008; Kraft et al. 2015). Some native pioneer species exhibit traits like those of exotic species such as light and water efficiency. These traits make them to adapt, grow and persist in altered forest conditions that result in either increased or decreased resources essential for growth due to natural and anthropogenic environmental disturbances (Everard et al. 1995; Schulten et al. 2014).

The assembly of natural plant communities is determined by several biotic and abiotic factors and their interaction effects along environmental gradients (Olthoff et al. 2015), which occur at multiple spatial scales (Dray et al. 2012). In this context, having IAPs in mind, it is important to identify plant communities that are vulnerable to invasion due to prevailing environmental factors (Hero et al. 2014). This study aims to describe existing distribution patterns of the dominant IAPs across two different spatial scales namely patch (forest reserve) and plot (on site within a forest reserve). The specific objectives of the study are (i) to identify controlling environmental factors at fine and broad scale, defining the IAPs distribution, and (ii) to determine community associations between native species and IAPs as an indicator of native plant species resilience.

\section{Methods}

\section{Physical location}

The eThekwini Municipal Area in which the Durban City falls under (Bengtsson et al. 2003) is situated in the KwaZulu-Natal (KZN) province of South Africa (29 $52^{\prime}$ $\left.\mathrm{S}, 31^{\circ} 01^{\prime} \mathrm{E}\right)$. It is situated in the Maputaland-Pondoland-Albany regional centre, which is one of the 35 global biodiversity hotspots (Boon et al. 2016; EPCPD 2016). The climate is subtropical with wet and warm summers, and mild dry winters. Temperature in eThekwini Municipality varies along the steep elevational gradient, from warm to cool as one moves from the coast to inland which has a maximum elevation of $904 \mathrm{~m}$ (EPCPD 2016). The mean annual temperature range is $16-20^{\circ} \mathrm{C}$, while the mean annual rainfall range is $550-1200 \mathrm{~mm}$ per annum (INR 2004). A total of 15 forest patches (mostly nature reserves, as well as one golf estate and one conservancy) which are included in the D'MOSS and are managed by different authorities, were selected for sampling (Table 1).

\section{Species sampling}

After an initial exploratory stage, the most abundant and widespread IAP species in each of the growth forms considered were included as target species. These were two tree IAPs namely Litsea glutinosa and Melia azedarach, three shrubs namely Chromolaena odorata, Lantana camara and Solanum mauritianum and two climbers namely Cardiospermum grandiflorum and Ipomoea purpurea. Seventy-four plots measuring $100 \mathrm{~m}^{2}$ $(10 \mathrm{~m} \times 10 \mathrm{~m})$ were surveyed, and a plot was established at every site where the target species were encountered in the forest patch. In the plots, the community structure (strata/vertical layers) was determined and the percentage canopy cover in each stratum was estimated. All native and invasive species in the shrub and tree layers were recorded for each stratum. The strata were categorised according to height as follows: lower trees $(>6 \mathrm{~m})$, tall shrubs $(>2-6 \mathrm{~m})$, low shrubs $(0.5-2 \mathrm{~m})$ and all climbers (regarded as a separate stratum because they grow across all layers). The total cover from all species within a plot was assessed according to Tansley's DAFOR scale (Emson et al. 2018): D = Dominant 
Table 1 Fifteen forest patches of the sampling sites within D'MOSS and their details on geographic and management authority of each. EKZNW stands for Ezemvelo KwaZulu-Natal Wildlife, PO for privately owned and EM for eThekwini Municipality

\begin{tabular}{llllllll}
\hline Forest patch & $\begin{array}{l}\text { Patch } \\
\text { codes }\end{array}$ & $\begin{array}{l}\text { Forest } \\
\text { type }\end{array}$ & $\begin{array}{l}\text { Management } \\
\text { agency }\end{array}$ & $\begin{array}{l}\text { Patch size } \\
\text { (ha) }\end{array}$ & $\begin{array}{l}\text { Connectivity } \\
\text { index }\end{array}$ & $\begin{array}{l}\text { Landscape index } \\
\text { (793757) }\end{array}$ & $\begin{array}{l}\text { Average elevation } \\
\text { (m asl) }\end{array}$ \\
\hline Springside & Spri & Scarp & EM & 21.1 & 38,046 & Very low & 584.0 \\
Krantzkloof & Kra & Scarp & EKZNW & 658.1 & $2,928,636$ & Very high & 455.7 \\
Iphithi & Ipit & Scarp & PO & 9.5 & 11,433 & Very low & 545.3 \\
Bluff Golf Estate & Bluf & Coastal & PO & 68.5 & 7240 & Very low & 21.5 \\
Buffelsdraai & Buf & Coastal & EM & 787 & $3,573,938$ & Very high & 252.2 \\
Burman Bush & Bur & Coastal & EM & 51.2 & 248,445 & Low & 47.3 \\
New Germany & New & Coastal & EM & 104.5 & 608,476 & Average & 358.5 \\
Palmiet & Palm & Coastal & EM & 63.5 & 206,754 & Low & 153.4 \\
Paradise Valley & Para & Coastal & EM & 153.5 & 533,837 & Average & 228.0 \\
Pigeon Valley & Pig & Coastal & EM & 13.9 & 79,324 & Very low & 84.3 \\
Roosfontein & Ros & Coastal & EM & 215.6 & $1,682,652$ & Very high & 158.0 \\
Virginia Bush & Vig & Coastal & EM & 49.8 & 208,275 & Low & 83.8 \\
Umhlanga Lagoon & Lag & Coastal & EKZNW & 30.9 & 137,533 & Low & 16.0 \\
North Park & Nor & Coastal & EKZNW & 48.9 & 330,616 & Low & 158.3 \\
Stainbank & StaB & Coastal & EKZNW & 224.2 & 524,635 & Average & 80.5
\end{tabular}

Low range $200000-300000$

High range 600000-800000

Landscape index ${ }^{1}$ (793757) is used to determine if forest patch has a low connectivity or high connectivity

(5); $\mathrm{A}=$ Abundant (4), $\mathrm{F}=$ Frequent (3), $\mathrm{O}=$ Occasional (2) and $\mathrm{R}=$ Rare (1). The overall species cover values were obtained by determining the average cover from all plots and used as a dependent variable with the environmental variables treated as independent. Species were identified using the most recent regional tree guide (Boon 2010). The Plants of Southern Africa website from the South African National Biodiversity Institute was accessed to confirm plants scientific names and floristic details (SANBI 2016). Furthermore, the Angiosperm Phylogeny website was accessed to confirm the most recent family assignment of the species (Stevens 2017).

\section{Environmental factors of plot scale and patch scale}

The plot-level environmental factors of geographic scale recorded included forest type (coastal or scarp), elevation $(\mathrm{m})$, latitude and longitude (measured with a GPS). Environmental variables were recorded as a percentage cover in each plot. These were exposed rock, gravel or surface stones, erosion and canopy gaps (inverse of canopy cover). At the patch level, the spatial variables for each nature reserve were obtained from digital cartography available in Google Earth Pro 7.2. The software Arc GIS 10.3.1 was used to convert layers to KML files and to create buffers of $500 \mathrm{~m}$ for each forest patch shape file. These buffers were embedded on Google Earth images of 2017 to create land-use polygons found within the buffer area. ArcGIS software was used to calculate the total area (hectares) of land represented by the polygons for each land use and to compute the number of forest patches found in the matrix (NP). Class area represents how much of the landscape is comprised by a patch type, which determines the size of a patch within a landscape. In forest fragmentation, it is important to know the total size of a target forest patch that exists within the landscape. The landscape similarity index or buffer index is the percentage of the landscape represented by one land-use type (McGarigal and Barbara 1995; Rutledge 2003). For this study, there are four landscape similarity indices, namely forest, grassland, residential and industrial areas.

\section{Connectivity calculations of forest patches}

For each forest patch sampled, a proximity buffer of 500 $\mathrm{m}$ was delineated for the identification of forest patches to be included in the calculation. The formula of patch connectivity incorporates the isolation of individual forest patches in relation to other forest patches found within the buffer. The patch connectivity index (PCI) was calculated as an area-based index weighted by distance and calculated as:

$$
\text { Connectivity Index }=\sum_{j}^{N} \frac{\mathrm{A}_{j}}{\text { Dist }_{j}}
$$

where $\mathrm{A}_{j}$ denotes the area $\left(\mathrm{m}^{2}\right)$ of a focal patch and Dist $\mathrm{j}_{j}$ is the squared distance $\left(\mathrm{m}^{2}\right)$ from the focal patch edge to 
another edge of a nearby patch in the landscape (Munguía-Rosas and Montiel 2014). In this calculation, the closest three patches to each focal patch were sampled to obtain their distances, which were then squared and calculated to obtain the focal forest patch index. Calculations relevant here are the mean connectivity index for each class (forest patch) and for all patches in the landscape. The patch connectivity index is used to calculate the degree of isolation. The landscape index is calculated as the average of all patch connectivity indices found within the landscape (Table 1). When a forest patch has a very low landscape index in comparison to that of the surrounding landscape, it means that the forest patch is highly isolated and when the landscape index of the patch is higher than that of the landscape it means it is less fragmented (McGarigal and Barbara 1995).

\section{Numerical data analyses \\ Floristic similarity}

The results of hierarchical clustering can be visualised using a dendrogram that indicates which plots are similar on the basis of their species composition. Species that occurred in ten or more plots were selected and used to classify plots into clusters. The dominant plant species occurring in each group were then used to name the plant communities that were in those clusters. The Paleontological Statistics Software Package (PAST v3.18) was used to analyse the dataset of plots with their species composition into clusters (Legendre and Legendre 1998; Hammer et al. 2001). The clustering of plant communities was performed using Ward's algorithm as a linkage method and with Euclidean distance as a distance measure. Ward's method uses an information criterion to join clusters in such a way that within-group variance is minimised (Hammer et al. 2001). The 15\% dissimilarity value was used as a cut-off in defining clusters as it best separated clusters of manageable and comparable size in terms of number of species.

\section{Ordination and variation partitioning of vegetation plot data}

Ordination is the arrangement of data units along one or more axes that express the range of variation existing within the dataset. The final result of an ordination is a graph that shows the variation of data units along two or more axes in a scatter-diagram. Constrained ordination characterises main trends of variation of data sets with respect to environmental factors and limits the illustration of unexplained variation (Legendre and Legendre 1998). The CANOCO 5.1 program package was used to run the ordination analysis (Ter Braak and Šmilauer 2012). Constrained ordinations were carried out on 32 species that occurred in ten or more plots of the whole data set, using the ordination method of canonical correspondence analysis (CCA) (Schulten et al. 2014). The CCA allows for the measurement of the amount of variation in the species distribution data that can be explained by a set of environmental variables (Borcard et al. 1992). Environmental variables used for the data analysis are shown in Table 2, and they are differentiated according to their spatial scale of occurrence, either at fine (plot) or broad (patch) scale. The plot scale analysis determines which niche factors influence the establishment of invasive species while the patch scale analysis determines which landscape attributes facilitate or impede the establishment of those species. This shows the scale of influence in the establishment and distribution of species (Ersoy 2016; Krishnadas et al. 2016).

Variation partitioning consists of a series of canonical ordinations that are constrained by a single set of explanatory variables with the complementary set used as co-variables. The variable sets that were used in this analysis are the environmental conditions at a plot scale and the variables explaining the spatial structure across the patch scale (Borcard et al. 1992; Legendre and Legendre 1998). The variation in species distribution is explained by the spatial structuring (Borcard et al. 1992). These are meant to test at which spatial level the species patterns of response are retained as influenced by the environmental factors operating at the two spatial scales (Dray et al. 2012). The spatial structuring of environmental factors addresses the problem of the relative contribution of different overlaid effects in space (Borcard et al. 1992).

Table 2 Environmental factors (and their abbreviations) used in the current study along with a description of their geographic scale. The fine scale refers to plot area $\left(100 \mathrm{~m}^{2}\right)$, and the broad scale refers to patch size (ranges from 9.5 to $787 \mathrm{ha}$ )

\begin{tabular}{lll}
\hline Environmental factor & Abbreviation & Spatial scale \\
\hline Tree IAPs & T-IAPs & Fine \\
Shrub IAPs & S-IAPs & Fine \\
Climbers IAPS & C-IAPs & Fine \\
Canopy cover & Canopy C & Fine \\
Canopy gap & Canopy G & Fine \\
Elevation & Altitude & Fine \\
Gravel & Gravel & Fine \\
Surface rocks & Rock & Fine \\
Patch size & PS & Broad \\
Patch connectivity index & PCI & Broad \\
Forest land similarity index & For-LSI & Broad \\
Grass land similarity index & Gra-LSI & Broad \\
Residence land similarity index & Res-LSI & Broad \\
Industry land similarity index & Ind-LSI & Broad \\
\hline
\end{tabular}




\section{Results}

\section{Species composition and diversity}

A total of 357 species from 75 families were identified in the forest plots (Fig. 1). Of these, there were 37 species that were considered abundant based on the number of plots in which they occurred and these species were illustrated in further analysis and discussion. The important species are listed in descending order of their overall average cover in Table 3.

\section{Floristic clustering}

A dendrogram with the similarity of plots from the different sites is shown in Fig. 2. It was obtained by fixing and computing a Euclidean distance at 15\%, which results in the formation of 13 vegetation clusters. Communities are named after the most dominant species occurring in those clusters (Table 4). A few of these communities are dominated by invasive alien plant species (IAPs), which makes them communities of interest. These are E (Chromolaena odorata), H (Cardiospermum grandiflorum) and K (Litsea glutinosa) (Table 4).

\section{Constrained ordination and variation partitioning}

The results of constrained ordination CCA of community $\mathrm{E}$ are shown in Fig. 3. The environmental variables with the strongest influence in the establishment of patterns in this community were patch size (PS) and patch connectivity index (PCI). The $\mathrm{H}$ and $\mathrm{K}$ communities were influenced by the positively correlated land-similarity indices of residential area and industrial area, canopy cover and elevation. Native species communities with an exclusive association with community E were A (Albizia adianthifolia), B (Protorhus longifolia) and C (Dalbergia obovate) (Fig. 3). The M (Strelitzia nicolai) communities occurred close to the $\mathrm{H}$ communities.

The results of constrained ordination CCA for all environmental variables are shown in Fig. 4. This analysis indicated tree IAPs, patch size and patch connectivity index were all key drivers of species distribution patterns. The tree IAPs Melia azedarach and Litsea glutinosa and the climber IAP Cardiospermum grandiflorum were correlated to canopy cover, while the other IAPs were correlated to canopy gaps (Fig. 4). The canonical axes test of significance is $P<0.01$.

The variation partitioning was significant $(P<0.01)$ for the two spatial levels tested for the plot (group I) and patch (group II) which has an intersection (III). More variables were explained at plot level (42.7\%) followed by patch level (33.8\%) and least by intersection (23.4\%).

The results of variation partitioning at plot level that are significant at $P<0.01$ are shown in Fig. 5 . The environmental factor of shrub IAPs was positively correlated to canopy gaps while the environmental factors elevation, climber IAPs and tree IAPs were positively correlated to canopy cover.

The results of variation partitioning at the patch scale are shown in Fig. 6. This figure illustrates that the

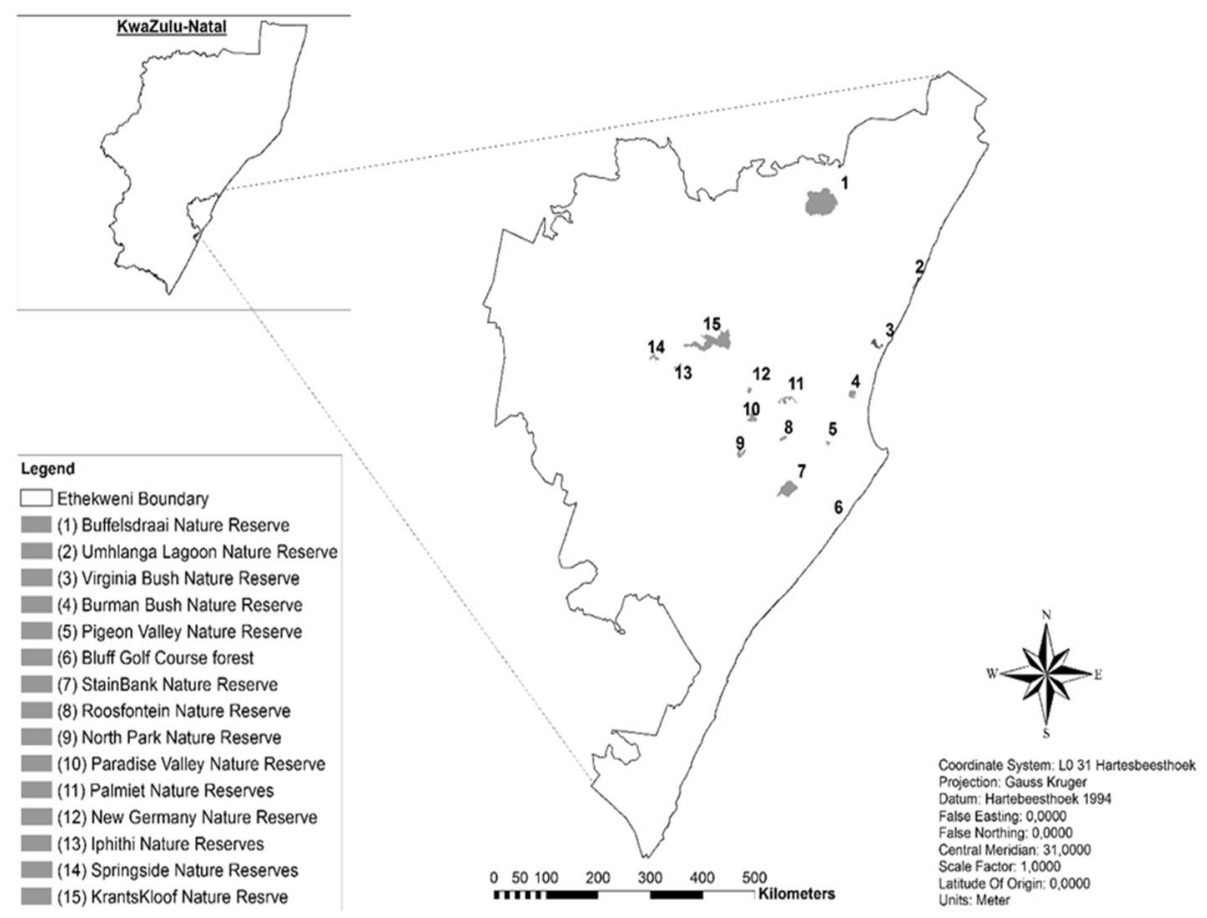

Fig. 1 Map of the study area (eThekwini Municipality) in KwaZulu-Natal, South Africa, indicating the 15 study sites 
Table 3 The important native and invasive species retained for analysis determined by average rank of cover of DAFOR scale for all plots

\begin{tabular}{|c|c|c|c|c|c|}
\hline Species & $\begin{array}{l}\text { Species } \\
\text { abbreviation }\end{array}$ & Family & $\begin{array}{l}\text { Functional } \\
\text { type }\end{array}$ & $\begin{array}{l}\text { Plot } \\
\text { occurrence }\end{array}$ & $\begin{array}{l}\text { Overall average } \\
\text { cover }\end{array}$ \\
\hline \multicolumn{6}{|l|}{ a) Native } \\
\hline Dalbergia obovata E.Mey. & DalbObov & Fabaceae & Scrambler & 42 & 1.57 \\
\hline Albizia adianthifolia (Schumach.) W.F. Wight & AlbiAdia & Fabaceae & Tree & 39 & 1.05 \\
\hline Monanthotaxis caffra Baill. & MonaCaff & Annonaceae & Scrambler & 32 & 1.00 \\
\hline Psychotria capensis (Eckl.) Vatke & PsycCape & Rubiaceae & Tree & 29 & 0.97 \\
\hline Protorhus longifolia (Bernh.ex C.Krauss) Engl. & ProtLong & Anacardiaceae & Tree & 31 & 0.91 \\
\hline Berkheya bergiana Ehrh. & BerkBerg & Asteraceae & Shrub & 21 & 0.82 \\
\hline Strelitzia nicolai Regel \& Körn. & StreNico & Strelitziaceae & Tree & 24 & 0.81 \\
\hline Isoglossa woodii Oerst. & IsogWood & Acanthaceae & Shrub & 16 & 0.78 \\
\hline Dalbergia armata & DalbArma & Fabaceae & Scrambler & 26 & 0.77 \\
\hline Smilax anceps Willd. & SmilAnce & Smilacaceae & Climber & 23 & 0.65 \\
\hline Englerophytum natalense (Sond.) T.D.Penn. & EnglNata & Sapotaceae & Tree & 20 & 0.55 \\
\hline Trimeria grandifolia (Hochst.) Warb. subsp. grandifolia & TrimGran & Salicaceae & Tree & 15 & 0.53 \\
\hline Dioscorea villosa $\mathrm{L}$. & DiosVill & Dioscoreaceae & Climber & 23 & 0.51 \\
\hline Croton sylvaticus Muell. Arg. & CrotSylv & Euphorbiaceae & Tree & 26 & 0.50 \\
\hline Rothmannia globosa (Hochst.) Keay & RothGlob & Rubiaceae & Tree & 17 & 0.49 \\
\hline Senecio tamoides DC. & SeneTamo & Asteraceae & Climber & 18 & 0.49 \\
\hline Canthium ciliatum (D.Dietr.) Kuntze & CantCili & Rubiaceae & Tree & 19 & 0.47 \\
\hline Kiggelaria africana L. & KiggAfri & Achariaceae & Tree & 21 & 0.46 \\
\hline Heteropyxis natalensis Harv. & HeteNata & Myrtaceae & Tree & 14 & 0.45 \\
\hline Zehneria scabra (L.f.) Sond. & ZehnScab & Curcubitaceae & Climber & 21 & 0.45 \\
\hline Combretum molle R.Br. ex G.Don & CombMoll & Combretaceae & Tree & 20 & 0.43 \\
\hline Canthium inerme (L.f.) Kuntze & Cantlner & Rubiaceae & Tree & 19 & 0.38 \\
\hline Tabernaemontana ventricosa Hochst. ex A.DC. & TabeVetr & Apocynaceae & Tree & 14 & 0.36 \\
\hline Baphia racemose (Hochst.) Baker & BaphRace & Fabaceae & Tree & 11 & 0.30 \\
\hline Bridelia micrantha (Hochst.) Baill. & BridMicr & Phyllanthaceae & Tree & 17 & 0.30 \\
\hline Ekebergia capensis Sparrm. & EkebCape & Meliaceae & Tree & 13 & 0.19 \\
\hline Dregea floribunda E.Mey. & DregFlor & Apocynaceae & Climber & 10 & 0.19 \\
\hline Trema orientalis (L.) Blume & TremOrie & Cannabaceae & Tree & 10 & 0.16 \\
\hline \multicolumn{6}{|l|}{ b) Invasive } \\
\hline Chromolaena odorata (L.) R.M.King & ChrmOdor & Asteraceae & Shrub & 38 & 1.09 \\
\hline Lantana camara $\mathrm{L}$. & LantCama & Verbenaceae & Shrub & 35 & 0.93 \\
\hline Cardiospermum grandiflorum Sw. & CardGran & Sapindaceae & Climber & 13 & 0.65 \\
\hline Litsea glutinosa (Lour.) C.B. Rob. & LitsSebi & Lauraceae & Tree & 15 & 0.57 \\
\hline Melia azedarach L. & MeliAzed & Meliaceae & Tree & 16 & 0.42 \\
\hline Ipomoea purpurea (L) Roth & IpomPurp & Convolvulaceae & Climber & 10 & 0.31 \\
\hline Parthenocissus quinquefolia (L.) Planch. & PartQuin & Vitaceae & Climber & 18 & 0.30 \\
\hline Passiflora suberosa L. & PassSube & Passifloraceae & Climber & 14 & 0.30 \\
\hline Solanum mauritianum Scop. & SolaMaur & Solanaceae & Shrub & 12 & 0.27 \\
\hline
\end{tabular}

environmental variables of patch size and patch connectivity index are strong drivers of species composition at the patch scale. Furthermore, these environmental variables are positively correlated to similarity indices of forest and grass lands and all show a positive influence on the establishment of the tree IAP Melia azedarach. 


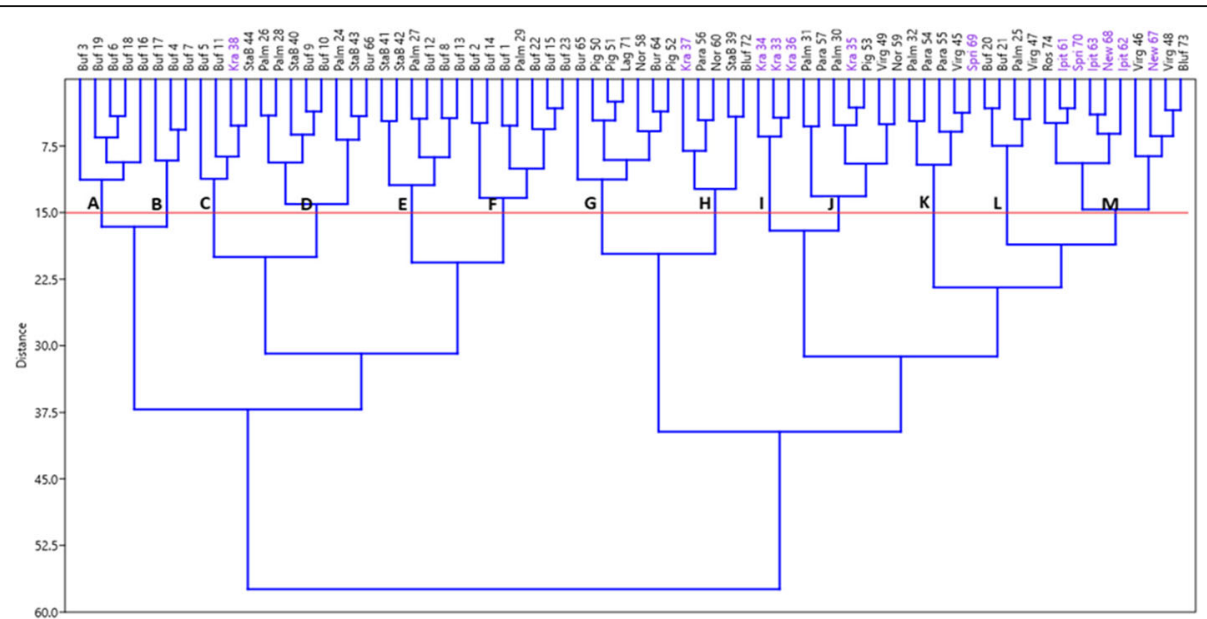

Fig. 2 Dendrogram showing the results of cluster analysis based on Ward-Euclidean for the species occurring in the plots. Community clusters delimited at 15\% dissimilarity are labelled with letters from $\mathrm{A}$ to $\mathrm{M}$, and the red line cuts clusters dominated by similar species. Codes on $x$-axis refer to all plot numbers of patches where the purple are from scarp forest and black from lowland forests

The environmental variables land similarity indices of residential and industrial area show a positive influence on the establishment of the IAPs Solanum mauritianum, Cardiospermum grandiflorum and Litsea glutinosa. Both sets of environmental factors have weaker correlation with the remaining five IAPs as shown in Fig. 6.

The Buffelsdraai Conservancy and Stainbank Nature Reserve have a high occurrence of community E plots as shown in Fig. 7. These are situated in lowland coastal forest, with large canopy gaps. Some of the properties of Buffelsdraai Conservancy are large patch size and high patch connectivity in relation to the landscape index. Stainbank Nature Reserve has an average patch size and average connectivity in relation to the landscape index (Table 1). The $\mathrm{K}$ community occurs in both scarp and lowland coastal forests, whereby the IAP is correlated to elevation and canopy cover. The $\mathrm{H}$ community also occur in both scarp and lowland coastal forests and the vine grows in association with both tree and shrub IAPs communities. The influence of the factors of patch size, patch connectivity index, similarity indices of forest and grass lands are prominent in lowland coastal forests.

\section{Discussion}

The environmental variables of the three different functional types (tree IAPs, shrub IAPs and climber IAPs) are not correlated, which means that they have different environmental niches, as illustrated in Figs. 3 and 4. The tree IAPs are distributed around the environmental variable of canopy cover while the climber and shrub IAPs

Table 4 Details of plant communities observed across the coastal lowland and scarp forests, and the number of their representative plots and forest patches each community occurred in

\begin{tabular}{|c|c|c|c|c|}
\hline Community label & Dominant species & Abbreviation & Plots & Patches \\
\hline $\bar{A}$ & Albizia adianthifolia & Aa Com & 5 & 1 \\
\hline B & Protorhus longifolia & PI Com & 3 & 1 \\
\hline C & Dalbergia obovata - Englerophytum natalense & Do-En Com & 4 & 3 \\
\hline $\mathrm{D}$ & Dalbergia armata & $\mathrm{Da} C o m$ & 8 & 4 \\
\hline E & Chromolaena odorata & Co Com & 6 & 3 \\
\hline $\mathrm{F}$ & Dalbergia obovata & Do Com & 7 & 2 \\
\hline G & Isoglossa woodii & Iw Com & 7 & 4 \\
\hline $\mathrm{H}$ & Cardiospermum grandiflorum & $\mathrm{Cg} \mathrm{Com}$ & 5 & 5 \\
\hline । & Englerophytum natalense & En Com & 3 & 1 \\
\hline J & Psychotria capensis & Pc Com & 7 & 6 \\
\hline K & Litsea glutinosa & Ls Com & 5 & 4 \\
\hline L & Trimeria grandifolia & Tg Com & 4 & 3 \\
\hline M & Strelitzia nicolai & Sn Com & 10 & 6 \\
\hline
\end{tabular}




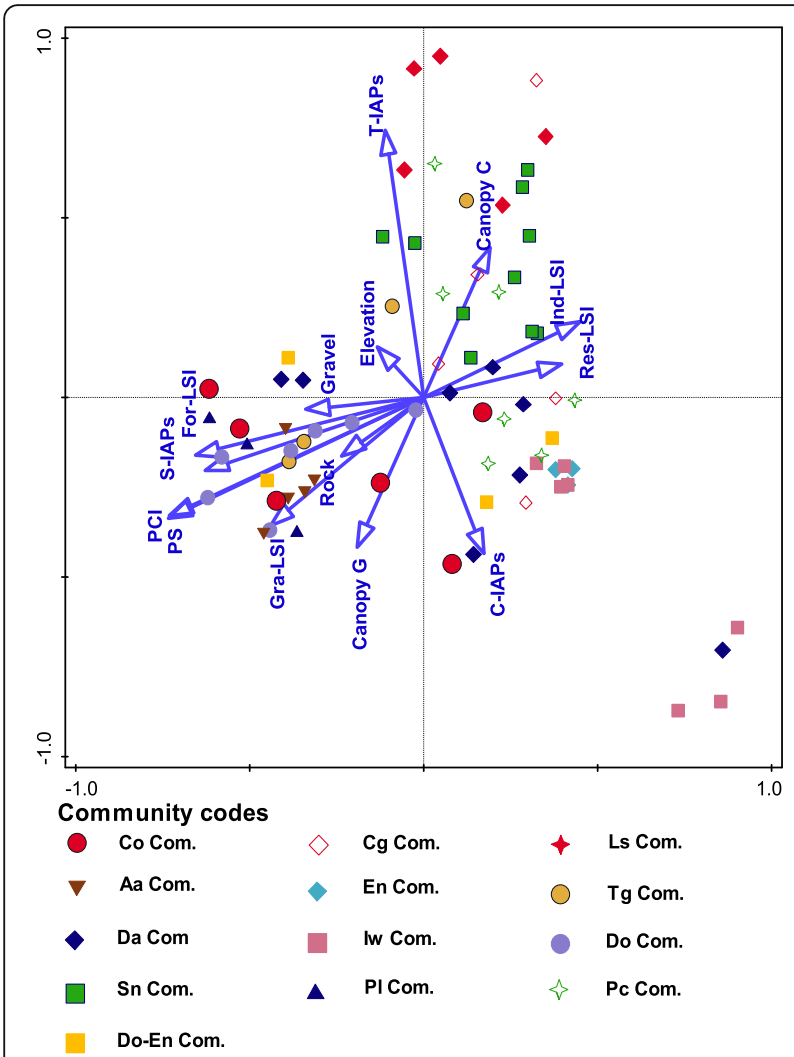

Fig. 3 Constrained ordination CCA for vegetation communities across the fifteen forest patches along the Durban Metropolitan Open Space System. Blue arrows and corresponding labels represent the direction and degree of various environmental variables (See Table 2 for details)

are distributed around the environmental variable of canopy gaps. The highly invaded communities $\mathrm{E}, \mathrm{H}$ and $\mathrm{K}$ are important because each represents one of the troublesome functional types occurring in forests which are tree, shrub and climber IAPs.

\section{Plot-scale environmental effects}

The environmental factors of high elevation and medium canopy cover are positively correlated and are strong determinants for tree IAPs (Fig. 5). These factors have a negative influence on diversity of IAPs and native species. Small and scattered canopy gaps found in higher elevation scarp forests explain the limited establishment of pioneer native species there (Everard et al. 1995). The IAPs that are most likely to become problem plants in higher elevation scarp forests are shade-tolerant and bird-dispersed species (Geldenhuys 2004, 2013). These IAPs grow in closed forest ecosystems and are ranked top in the hierarchy of species competitiveness, making them important species for control (Everard et al. 1995).

In canopy gaps, species diversity is high for both alien and native species. This indicates that forest habitat openness increases the establishment of alien species

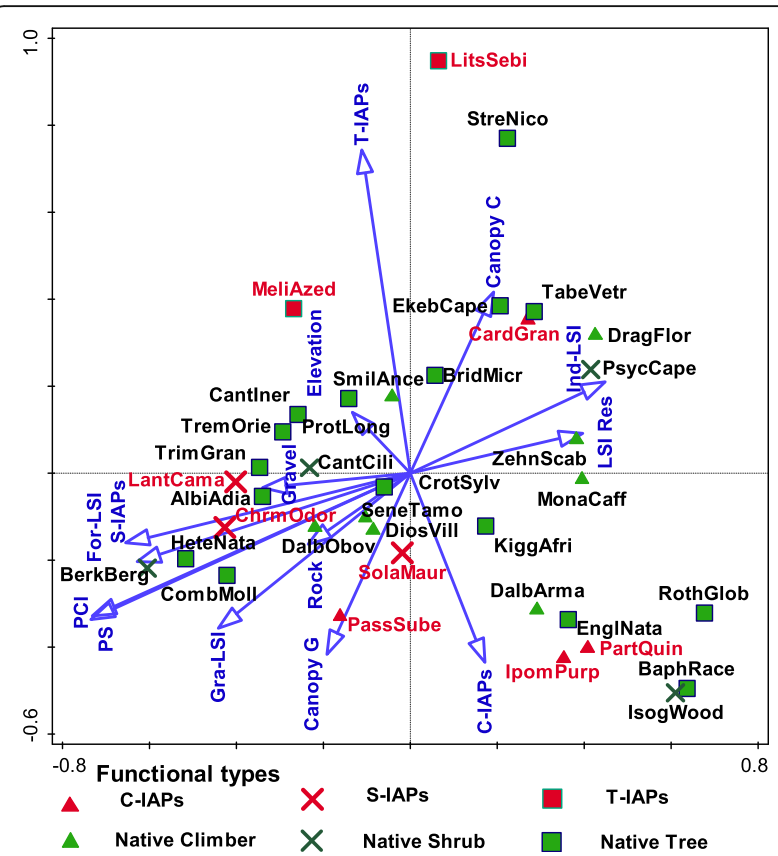

Fig. 4 Constrained ordination CCA of species distribution across the environmental factors studied (see Table 2 for details). Species codes are detailed in Table 3. Blue arrows and corresponding labels represent the environmental factors, while red labels are IAPs and black labels are native species

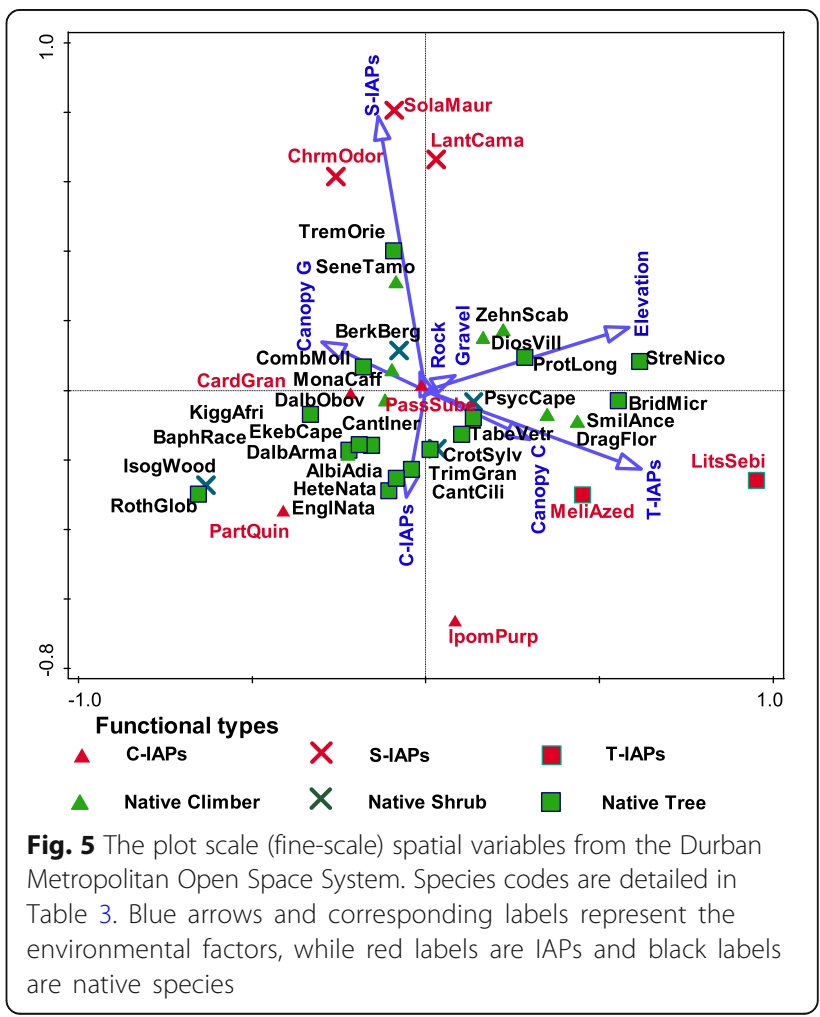




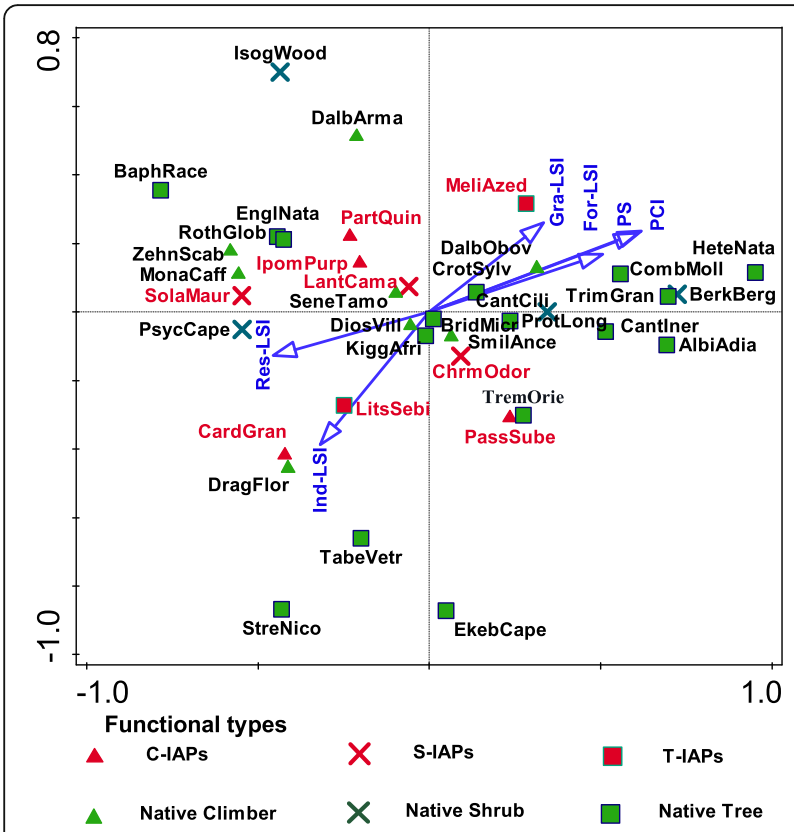

Fig. 6 The patch scale (broader-scale) spatial variables from the Durban Metropolitan Open Space System. Species codes are detailed in Table 3. Blue arrows and corresponding labels represent the environmental factors, while red labels are IAPs and black labels are native species

(Charbonneau and Fahrig 2004), which are generally shade intolerant (Geldenhuys 2013). In this study, shrub and climber IAPs were found in canopy gaps (Fig. 5), meaning that the success of invasion by these IAPs is attributed to canopy gaps, species attributes and ecosystem properties (Deckers et al. 2005). Coastal and scarp forests in Durban and nearby areas are occasionally exposed to strong winds that can blow down adult trees growing on generally shallow soils (Everard et al. 1995; Botzat et al. 2015; Vecchio et al. 2015). The lowland coastal forests are characterised by communities of early successional species and are thus dominated by shade-intolerant species (Everard et al. 1995). The physical disruption of the land surface facilitates invasion due to reduced cover and vigour of native species (Davis et al. 2000), and the exposure to light and greater temperature fluctuations which increases nitrogen mineralisation (D'Antonio and Meyerson 2002). Forest gaps that are created in this manner assist invaders to successfully fill unoccupied niches because of the reduction of native species due to degradation (Mack and D'Antonio 1998; Goodall 2000; Wilson et al. 2007; Gaertner et al. 2009). The light in canopy gaps limits late successional species (mostly natives), and the resultant increase in mineral resource levels will favour fast-growing early successional species and this may include invader species (D'Antonio and Meyerson 2002). Canopy gaps are more prevalent in the forest patches found in lowland

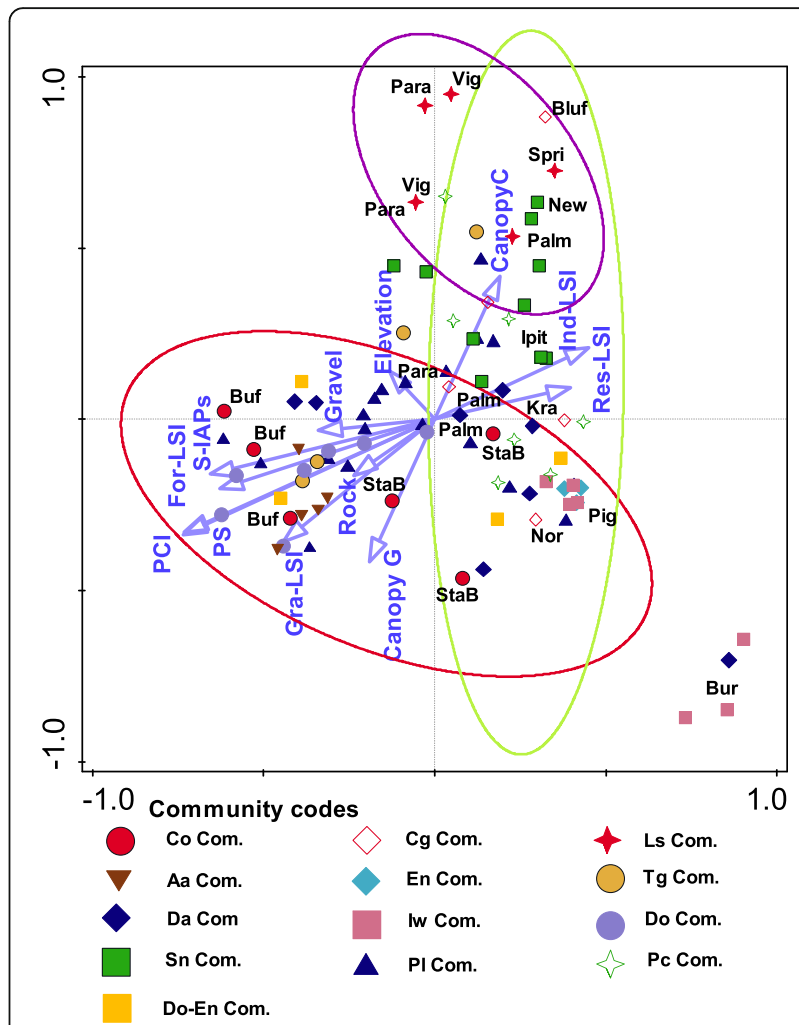

Fig. 7 Envelop mapping of the three important invasive species communities found in association with native species communities that occur in 15 forest patches found in the Durban Metropolitan Open Space System. Blue arrows and corresponding labels represent the environmental factors. Community codes are detailed in Table 4

coastal forests. This finding implies that strong wind exposure is more severe in the lowland coastal forest than the scarp forest (Everard et al. 1995).

\section{Patch-scale environmental effects}

The size and types of matrices surrounding forest patches have an influence on the establishment of invasive species (Hansen and Clevenger 2005; Bartuszevige et al. 2006; Botzat 2012; Nitoslawski and Duinker 2016). The niches that have high numbers of IAPs correspond with the areas that have high values for the correlated similarity indices of residence and industry (Fig. 6). Spatial factors such as the close proximity of forest patches to propagule sources could be the reason why urban forests that have high residential and industrial matrix values are subjected to high levels of invasion by alien species (Vidra 2004). Residential areas also influence invasion of forest patches due to high population, pollution (Grunewald et al. 2018) and by the growing of exotic plants for aesthetic values by property occupiers (Nitoslawski and Duinker 2016). This explains why human-derived land uses increase propagule pressure from transformed land matrices into natural forest 
habitats (González-Moreno et al. 2013). In the current study, those forest patches characterised by high patch size and patch connectivity index (and, simultaneously, medium land similarity indices of forest and grassland) have poor diversity of invasive species (Fig. 6). More isolated patches with a high level of land-use change affect ecosystem integrity, which provides an opportunity for IAPs to establish (Borgmann and Rodewald 2005). Therefore, the proportion of pioneer invasive species on site are an indicator that some form of disturbance occurs in that forest community, but resilience to invasion is shown by a greater patch size (Hernández-Ruedas et al. 2014). There is a weak influence of patch size, patch connectivity index, and similarity indices of forest and grass lands on shrub IAPs distribution at the patch scale in variation partitioning (Fig. 6). This indicates that the interaction of canopy gap with these variables is crucial for species displacement. The level of connectivity and the spatial arrangement of forest corridors do affect the rate of invasion (Bartuszevige et al. 2006). In the current study, the poor invasion of forest patches characterised by these factors indicates that the more connected forest patches are, the more resilient they are to the risks of invasion due to a lower ratio of edge area to patch size which limits the establishment of IAPs. The more edge habitat a forest patch has, the more vulnerable it is to invasion by alien invasive plants (Hansen and Clevenger 2005). Solar radiation changes along forest edges and often influences the state of soil moisture and temperature, which creates a micro-climate which promotes the germination of IAP seeds in the seedbank (Bonanomi et al. 2018).

\section{The distribution of communities}

The E (Chromolaena odorata) community is influenced by many environmental factors that are positively correlated with canopy gaps (Fig. 7). Canopy gaps are found mostly in lowland coastal forest patches (Table 1), and the three IAP functional types do occur in them (Fig. 7). The high proximity to non-managed forest patches found outside boundaries of nature reserves act as corridors that could be occupied by plants with wind-dispersed invasive seeds. The configuration of a landscape and the proximity to propagule sources increases dispersal towards nature reserves which increases invasion risk (Borgmann and Rodewald 2005; Botzat 2012). Management of IAPs outside the boundaries of forest reserves might be poor; therefore, adjacent forest patches that are invaded may be propagule sources of wind-dispersed IAPs as suggested by Macdonald and Jarman (1985). So, such forest patches occurring outside of nature reserves, even when they have low transformation and resembling natural habitats, are potential propagule sources of IAPs regeneration in nearby forest reserves (Botzat 2012).

The $\mathrm{E}$ community is more pronounced in patches of lowland coastal forest, and the $\mathrm{K}$ community is more pronounced in patches of high-elevation scarp forest. Additionally, the $\mathrm{H}$ community is found in patches of both types of coastal forests (Fig. 7). A study on IAPs ranked the effects of species functional types and found that the shrub and climber IAPs have high ecological impact on species diversity and distribution extent when compared with the tree IAPs. Furthermore, the two functional types are difficult to control (Macdonald and Jarman, 1985). The patterns of forest community assembly relate directly to the forest dynamics and to the species adapting to specific environmental factors or disturbance regimes (Geldenhuys 2013). Factors that determine the levels of invasion are propagule pressure and suitable traits for establishment (Matthews et al. 2009). Furthermore, species establishment is determined by suitable traits for establishment traits and the site condition. A few lowland coastal forest patches had occurrence of all three IAP functional type clusters. Invasive species that co-exist are likely to vary in their impact and their niche preference (Kuebbing et al. 2014). Multiple invasions lead to high risk of transformation to novel communities. The $\mathrm{K}$ community is associated with canopy cover in both forest types in an elevational range of $80-580 \mathrm{~m}$ asl. The species of the $\mathrm{K}$ vegetation community are shade-tolerant which makes them a great threat to the integrity of natural forest (Geldenhuys 2004). This is because shade-tolerant IAPs exhibit advanced regeneration and establishment properties under closed canopies, by taking advantage of the small canopy gaps to grow and reach the canopy (West et al. 2000). These species usually form dense populations of saplings in the forest understory (Geldenhuys 2013).

The ordination association of the IAP community $\mathrm{E}$ with $\mathrm{A}, \mathrm{I}, \mathrm{D}$ and $\mathrm{F}$ communities is an indication that these species are resilient to the prevailing forest dynamics of their niche. The ordination association of the IAP community $\mathrm{K}$ with J, $\mathrm{L}$ and $\mathrm{M}$ communities is an indicator that these native species can deal with the same environmental factors that are promoting the establishment of IAPs. Species that co-occur in these environmental conditions are those that have developed strategies for coping and survival (Gallien et al. 2014). Therefore, these species can be used to pre-empt invasion in forest restoration projects. The climber IAPs occur in canopy gaps and grow to the level of the tree canopy. Climber IAPs grow well in damp environments with a preference for forest margins and canopy gaps, where they get adequate light levels for growth. Furthermore, the 
tendrils of the vines and lianas help them to twirl around other plants allowing them to climb over $10 \mathrm{~m}$ in height, where they then form large canopy cover to outcompete other plants for light (Simelane et al. 2011). Competitive species replace non-competitive ones in niches that have resources manipulated by disturbance. Native tree species of the coastal forest of KwaZulu-Natal that have shown resilience in canopy gaps include Croton syivaticus (Everard et al. 1995), Canthium inerme, Trema orientalis, Albizia adianthifolia, Bridelia micrantha and Ekebergia capensis (Grainger 2012). Forest site restoration is most likely to be successful when these native species are planted to occupy any empty niches. This suggests that those native species that remain in invaded environments are likely to persist (Schulten et al. 2014).

\section{Conclusion}

The higher elevations in scarp coastal forests and small canopy gaps favour the occurrence of tree IAPs while limiting other alien invasions. In scarp forests, early control of tree IAPs under canopy can avoid the loss of biodiversity and economic costs before the species can establish and reach canopy level. Some native species, which are found in association with tree, shrub and climber IAPs are resilient when IAPs establish around them. This informs forest restoration projects that those species can be considered for planting. The risk of novel community development is high in lowland coastal forests and this can be attributed to the high frequency of canopy gaps that occur there. This finding makes coastal forests a high priority area for the control of IAPs relative to scarp forests. Forest patches with a high buffer matrix of residential and industrial surroundings have a high diversity of IAPs. The creation of outside boundary buffers to control the influx of IAPs is recommended for such situations. Large patch size of forests and high connectivity of forest patches have shown to result in low levels of invasion by IAPs.

\section{Abbreviations}

asl: Above sea level; CCA: Canonical correspondence analysis; D'MOSS: Durban Metropolitan Open Space System; EMA: eThekwini Municipal Area; IAPs: Invasive alien plant species

\section{Acknowledgements}

The authors would like to thank NRF for financial support through the University of KwaZulu-Natal. The management of eThekwini Municipality and Ezemvelo KwaZulu-Natal Wildlife for granting access to the forest nature reserves. Additional thanks to Mr. S Mjaja for assistance in GIS use and applications.

\section{Funding}

The National Research Foundation (NRF) funds LZM's academic and living costs which includes data collection and analysis, travel, meals and accommodation.

Availability of data and materials

Please contact author.

\section{Authors' contributions}

LZM designed the study, collected, organised the data for analysis and wrote the manuscript. EJJS is the main supervisor on the study design, data collection, data analysis and manuscript write-up. SP co-supervised on the study design, data collection, data analysis and manuscript write-up. All authors read and approved the final manuscript.

\section{Authors' information}

LZM, currently PhD Candidate at the University of KwaZulu-Natal, School of Agricultural, Earth and Environmental Sciences.

EJJS, Senior Lecturer at the University of KwaZulu-Natal, School of Agricultural, Earth and Environmental Sciences.

ŞP, Professor at the University of KwaZulu-Natal, School of Agricultural, Earth and Environmental Sciences.

Ethics approval and consent to participate

Not applicable

Consent for publication

Not applicable

\section{Competing interests}

The authors declare that they have no competing interests.

\section{Publisher's Note}

Springer Nature remains neutral with regard to jurisdictional claims in published maps and institutional affiliations.

Received: 8 August 2018 Accepted: 30 November 2018

Published online: 28 December 2018

\section{References}

Bartuszevige, A. M., Gorchov, D. L., \& Raab, L. (2006). The relative importance of landscape and community features in the invasion of an exotic shrub in a fragmented landscape. Ecography, 29, 213-222.

Bengtsson, J., Angelstam, P., Elmqvist, T., Emanuelsson, U., Folke, C., Ihse, M. Moberg, F., \& Nyström, M. (2003). Reserves, resilience and dynamic landscapes. A Journal of the Human Environment, 32(6), 389-396. https://doi. org/10.1579/0044-7447-32.6.389.

Bergsten, A., Bodin, Ö., \& Ecke, F. (2013). Protected areas in a landscape dominated by logging - A connectivity analysis that integrates varying protection levels with competition-colonization tradeoffs. Biological Conservation, 160, 279-288. https://doi.org/10.1016/j.biocon.2013.01.016.

Bierwagen, B. G. (2005). Predicting ecological connectivity in urbanizing landscapes. Environment and Planning B: Planning and Design, 32(5), 763-776.

Bonanomi, G., Incerti, G., Abd El-Gawad, A., Sarker, T., Stinca, A., Motti, R., Cesarano, G., Teobaldelli, M., Saulino, L., Cona, F., Chirico, G., Mazzoleni, S., \& Saracino, A. (2018). Windstorm disturbance triggers multiple species invasion in an urban Mediterranean forest. Biogeosciences and Forestry, 11(1), 64-71.

Boon, R. (2010). Pooley's Trees of Eastern Southern Africa: A Complete Guide. Durban: Flora and Fauna Publication Trust.

Boon, R., Cockburn, J., Douwes, E., Govender, N., Ground, L., Mclean, C., Roberts, D., Rouget, M., \& Slotow, R. (2016). Managing a threatened savanna ecosystem (KwaZulu-Natal Sandstone Sourveld) in an urban biodiversity hotspot: Durban, South Africa. Bothalia, 46(2), 1-12.

Borcard, D., Legendre, P., \& Drapeau, P. (1992). Partialling out the spatial component of ecological variation. Ecological Society of America, 73(3), 1045-1055.

Borgmann, K. L., \& Rodewald, A. D. (2005). Forest restoration in urbanizing landscapes: interactions between land uses and exotic shrubs. Restoration Ecology, 13(2), 334-340.

Botzat, A. (2012). Fragment quality rather than matrix habitat shapes forest regeneration in a South African mosaic-forest landscape. PhD Thesis. Marburg: Philipps University.

Botzat, A., Fischer, L., \& Farwig, N. (2015). Regeneration potential in South African forest fragments: extinction debt paid off or hampered by contemporary matrix modification? Plant Ecology, 216, 535-551.

Charbonneau, N. C., \& Fahrig, L. (2004). Influence of canopy cover and amount of open habitat in the surrounding landscape on proportion of alien plant species in forest sites. Ecoscience, 11(3), 278-281. 
D'Antonio, C., \& Meyerson, L. A. (2002). Exotic plant species as problems and solutions in ecological restoration: a synthesis. Restoration Ecology, 10(4), 703-713.

Davis, M. A., Grime, J. P., \& Thompsom, K. (2000). Fluctuating resources in plant communities: a general theory of invasibility. Journal of Ecology, 88(1), 528-534.

Deckers, D., Verheyen, K., Hermy, M., \& Muys, B. (2005). Effects of landscape structure on the invasive spread of black cherry Prunus serotina in an agricultural landscape in Flanders, Belgium. Ecography, 28(1), 99-109.

Dray, S., Pélissier, R., Couteron, P., Fortin, M. J., Legendre, P., Peres-Neto, P. R., Bellier, E., Bivand, R., Blanchet, F. G., De Cáceres, M., Dufour, A. B., Heegaard, E. , Jombart, T., Munoz, F., Oksanen, J., Thioulouse, J., \& Wagner, J. J. (2012). Community ecology in the age of multivariate multiscale spatial analysis. Ecological Monographs, 83(3), 257-275.

Emson, D., Sayer, C. D., Bennion, H., Patmore, I. R., \& Rioual, P. (2018). Mission possible: diatoms can be used to infer past duckweed (lemnoid Araceae) dominance in ponds. Journal of Paleolimnology, 60(2), 209-221.

EPCPD. (2016). Durban's systematic conservation assessment (pp. 1-93). Durban: eThekwini Municipality: Environmental Planning \& Climate Protection Department.

Ersoy, E. (2016). Landscape ecology practices in planning: landscape connectivity and urban networks. In M. Ergen (Ed.), Sustainable urbanization (pp. 291-316) Rijeka: Intech

Everard, D. D., Midgley, J. J., \& van Wyk, G. F. (1995). Dynamics of some forests in Kwa Zulu-Natal, South Africa, based on ordinations and size-class distributions. South African Journal of Botany, 61(6), 283-292.

Funk, J. L. (2008). Differences in plasticity between invasive and native plants from a low resource environment. Journal of Ecology, 96(6), 1162-1173.

Gaertner, M., Den Breeyen, A., Cang, H., \& Richardson, D. M. (2009). Impacts of alien plant invasions on species richness in Mediterranean-type ecosystems: a meta-analysis. Progress in Physical Geography, 33(3), 319-338.

Galic, N., Sullivan, L. L., Grimm, V., \& Forbes, V. E. (2018). When things don't add up: quantifying impacts of multiple stressors from individual metabolism to ecosystem processing. Ecology Letters, 21(4), 568-577.

Gallien, L., Carboni, M., \& Munkem, T. (2014). Identifying the signal of environmental filtering and competition in invasion patterns - a contest of approaches from community ecology. Methods in Ecology and Evolution, 5, 1002-1011.

Geldenhuys, C. J. (2004). Concepts and process to control invader plants in and around natural evergreen forest in South Africa. Weed Technology, $18,1386-1391$

Geldenhuys, C. J. (2013). Converting invasive alien plant stands to natural forest nature's way: overview, theory, and practice. In: S. Jose, H. P. Singh, D. R. Batish, R. K. Kohli (Eds.). Invasive Plant Ecology (pp. 217-238). New York: CRC Press.

González-Moreno, P., Pino, J., Carreras, D., Basnou, C., Fernández-Rebollar, I., \& Vilá, M. (2013). Quantifying the landscape influence on plant invasions in Mediterranean coastal habitats. Landscape Ecology, 28(5), 891-903.

Goodall, J. M. (2000). Monitoring serial changes in coastal grasslands invaded by Chromolaena odorata (L.) R.M. King and Robinson. University of Natal, Pietermaritzburg. Available from http://researchspace.ukzn.ac.za/handle/ $10413 / 10246$

Grainger, M. J. (2012). An evaluation of coastal dune forest restoration in northern KwaZulu-Natal, South Africa. Thesis. Doctor of Philosophy (Zoology), University of Pretoria. Retrieved from http://hdl.handle.net/2263/25171.

Grunewald, K., Xie, G., \& Wüstemann, H. (2018). The multiple benefits of urban green-ecosystem services assessment. In: K. Grunewald, J. Li, G. Xie, L. Kümper-Schlake (Eds.). Towards green cities: urban biodiversity and ecosystem services in China and Germany (pp. 43-104). Cham: Springer International Publishing.

Hammer, Ø., Harper, D. A. T., \& Ryan, P. D. (2001). PAST: paleontological statistics software package for education and data analysis. Palaeontologia Electronica, 4(1), 1-9.

Hansen, M. J., \& Clevenger, A. P. (2005). The influence of disturbance and habitat on the presence of non-native plant species along transport corridors. Biological Conservation, 125(2), 249-259.

Heinrichs, S., \& Pauchard, A. (2015). Struggling to maintain native plant diversity in a peri-urban reserve surrounded by a highly anthropogenic matrix. Biodiversity and Conservation, 24(11), 2769-2788.

Henderson, L. (2001). Alien weeds and invasive plants. Plant Protection Research Institute Handbook No. 12. Pretoria: Agricultural Research Council.
Hernández-Ruedas, M. A., Arroyo-Rodríguez, V., Meave, J. A., Martínez-Ramos, M., Ibarra-Manríquez, G., Martínez, E., Jamangapé, G., Melo, F. P. L., \& Santos, B. A. (2014). Conserving tropical tree diversity and forest structure: the value of small rainforest patches in moderately-managed landscapes. PLoS One, 9(6), 1-10.

Hero, J. M., Butler, S. A., Lollback, G. W., \& Castley, J. G. (2014). Determinants of tree assemblage composition at the mesoscale within a subtropical eucalypt forest. PLoS One, 9(12), 1-18.

INR. (2004). Rural agricultural land potential assessment and agribusiness policy for ethekwini: Ethekwini agricultural status quo. Scottsville: Institute of Natural Resources.

Jacq, F. A., Hladik, A., \& Bellefontaine, R. (2005). Dynamics of the introduced tree Litsea glutinosa (Lauraceae) in Mayotte Island: is it an invasive species? Revue d Ecologie, 60, 21-32.

Kraft, N. J. B., Godoy, O., \& Levine, J. M. (2015). Plant functional traits and the multidimensional nature of species coexistence. Proceedings of the National Academy of Sciences, 112(3), 797-802.

Krings, A., \& Braham, R. R. (2005). Guide to tendrillate climbers of Costa Rican mountains. Blackwell Publishing Asia.

Krishnadas, M., Kumar, A., \& Comita, L. S. (2016). Environmental gradients structure tropical tree assemblages at the regional scale. Journal of Vegetation Science, 27(6), 1117-1128.

Kuebbing, S. E., Classen, A. T., \& Simberloff, D. (2014). Two co-occurring invasive woody shrubs alter soil properties and promote subdominant invasive species. Journal of Applied Ecology, 51, 124-133.

LaPoint, S., Balkenhol, N., Hale, J., Sadler, J., \& van der Ree, R. (2015). Ecological connectivity research in urban areas. Functional Ecology, 29(7), 868-878.

Lawes, M. J., Macfarlane, D. M., \& Eeley, H. A. C. (2004). Forest landscape pattern in the KwaZulu-Natal midlands, South Africa: 50 years of change or stasis? Austral Ecology, 29, 613-623.

Legendre, P., \& Legendre, L. (1998). Numerical Ecology (2nd ed.). Netherlands: Elsevier Science B.V.

Lehosmaa, K., Jyväsjärvia, J., Virtanena, R., Ilmonend, J., Saastamoinene, J., \& Muotkaa, T. (2017). Anthropogenic habitat disturbance induces a major biodiversity change in habitat specialist bryophytes of boreal springs. Biological Conservation, 215(215), 169-178.

Leishman, M. R., Haslehurst, T., Ares, A., \& Baruch, Z. (2007). Leaf trait relationships of native and invasive plants: community- and global-scale comparisons. New Phytologist, 176(3), 635-643

Lepczyk, C. A., Aronson, M. F. J., Evans, K. L., Goddard, M. A., Lerman, S. B., \& Maclvor, J. S. (2017). Biodiversity in the city: Fundamental questions for understanding the ecology of urban green spaces for biodiversity conservation. BioScience, 67(9), 799-807.

Macdonald, I. A. W., \& Jarman, M. L. (Eds.) (1985). Invasive alien plants in the terrestrial ecosystems of Natal, South Africa. CSIR. South Africa: Foundation for Research Development.

Mack, M. C., \& D'Antonio, C. M. (1998). Impacts of biological invasions on disturbance regimes. Trends in Ecology \& Evolution, 13(5), 195-198.

Matthews, J. W. Peralta, A. L., Soni, A., Baldwin, P., Kent, A. D., \& Endress, A. D. (2009). Local and landscape correlates of non-native species invasion in restored wetlands. Ecography, 32(32), 1031-1039.

McGarigal, K., \& Barbara, J. M. (1995). FRAGSTATS: spatial pattern analysis program for quantifying landscape structure. (pp. 1-122). Pacific Northwest Research Station.

Munguía-Rosas, M. A., \& Montiel, S. (2014). Patch size and isolation predict plant species density in a naturally fragmented forest. PLoS One, 9(10), 1-7. https:// doi.org/10.1371/journal.pone.0111742.

Muster, C., Meyer, M., \& Sattler, T. (2014). Spatial arrangement overrules environmental factors to structure native and non-native assemblages of synanthropic harvestmen. PLoS One, 9(3), 1-11.

Naicker, R., Rouget, M., \& Mutanga, O. (2016). Assessing habitat fragmentation of the KwaZulu-Natal Sandstone Sourveld, a threatened ecosystem. Bothalia African Biodiversity \& Conservation, 46, 1-10.

Nitoslawski, S., \& Duinker, P. (2016). Managing tree diversity: a comparison of suburban development in two Canadian cities. Forests, 7(6), 119.

Nor, A. N. M., Corstanje, R., Harris, J. A., Grafius, D. R., \& Siriwardena, G. M. (2017). Ecological connectivity networks in rapidly expanding cities. Heliyon, 3(6), e00325. https://doi.org/10.1016/j.heliyon.2017.e00325.

Olckers, T. (1999). Biological control of Solanum mauritianum Scopoli (Solanaceae) in South Africa: a review of candidate agents, progress and future prospects. African Entomology, 1(1), 65-73. 
Olthoff, A., Martı́nez-Ruiz, C., \& Alday, J. G. (2015). Distribution patterns of forest species along an Atlantic-Mediterranean environmental gradient: an approach from forest inventory data. Forestry, 89, 46-54.

Padayachee, A. L., Irlich, U. M., Faulkner, K. T., Gaertner, M., Procheş, Ş., Wilson, J. R. U., \& Rouget, M. (2017). How do invasive species travel to and through urban environments? Biological Invasions, 19(12), 3557-3570. https://doi.org/10. 1007/s10530-017-1596-9.

Peerbhay, K., Mutanga, O., \& Ismail, R. (2016). The identification and remote detection of alien invasive plants in commercial forests: An overview. South African Journal of Geomatics, 5(1), 49-67.

Procheş, Ş., Wilson, J. R., Veldtman, R., Kalwij, J. M., Richardson, D. M., \& Chown, S. L. (2005). Landscape corridors: possible dangers? Science, 310(5749), 779-783.

Richardson, D. M., Pyšek, P., Rejmánek, M., Barbour, M. G., Panetta, F. D., \& West, C. J. (2000). Naturalization and invasion of alien plants: concepts and definition. Diversity and Distributions, 6, 93-107.

Rutledge, D. (2003). Landscape indices as measures of the effects of fragmentation: can pattern reflect process? DOC Science Internal Series 98. Wellington: Department of Conservation.

SANBI. (2016). Plants of southern Africa: (Botanical Database of Southern Africa). Retrieved 09 June 2018, from South African National Biodiversity Institute http://newposa.sanbi.org/

Schulten, J. R., Cole, T. C., Cordell, S., Publico, K. M., Ostertag, R., Enoka J, E., \& Michaud, J. D. (2014). Persistence of native trees in an invaded Hawaiian lowland wet forest: experimental evaluation of light and water constraints. Pacific Science, 68(2), 267-285.

Simelane, D. O., Fourie, A., \& Mawela, K. V. (2011). Prospective agents for the biological control of Cardiospermum grandiflorum Sw. (Sapindaceae) in South Africa. African Entomology, 19(2), 269-277.

Singer, A., Johst, K., Banitz, T., Fowler, M. S., Groeneveld, J., Gutiérrez, A. G., Hartig, F., Krug, R. M., Liess, M., Matlack, G., Meyer, K. M., Péer, G., Radchuk, V., Voinopol-Sassu, A., \& Travis, J. M. J. (2016). Community dynamics under environmental change: how can next generation mechanistic models improve projections of species distributions. Ecological Modelling journal, 326, 63-74.

Stevens, P. F. (2017). Angiosperm phylogeny website. Version 14, (Version 14). Retrieved 09 June 2018, from Hilary Davis http://www.mobot.org/MOBOT/ research/APweb/.

Ter Braak, C. J. F., \& Šmilauer, P. (2012). Multivariate analysis of ecological data using CANOCO Canoco reference manual and user's guide: software for ordination (Version 4.5, $496 \mathrm{p}$ ).

Threlfall, C. G., Ossola, A., Hahs, A. K., Williams, N. S. G., Wilson, L., \& Livesley, S. J. (2016). Variation in vegetation structure and composition across urban green space types. Frontiers in Ecology and Evolution, 4(66), 1-12.

Totland, Ø., Nyeko, P., Bjerknes, A., Hegland, S. J., \& Nielsen, A. (2005). Does forest gap size affects population size, plant size, reproductive success and pollinator visitation in Lantana camara, a tropical invasive shrub? Forest Ecology and Management, 215(1-3), 329-338.

Tourn, G. M., Menvielle, M. F., Scopel, A. L., \& Pidal, B. (1999). Clonal strategies of a woody weed: Melia azedarach. Plant and Soil, 217(1), 111-117.

van Wyk, G. F., Everard, D. A., Midgley, J. J., \& Gordon, I. G. (1996). Classification and dynamics of a southern African subtropical coastal lowland forest. South African Journal of Botany, 62(3), 133-142.

Vecchio, S. D., Pizzo, L., \& Buffa, G. (2015). The response of plant community diversity to alien invasion: evidence from a sand dune time series. Biodiversity and Conservation, 24(2), 371-392.

Vidra, R. L. (2004). Implications of exotic species invasion for restoration of urban riparian forests. Degree of Doctor of Philosophy. North Carolina: North Carolina State University.

West, A. G., Midgley, J. J., \& Bond, W. J. (2000). Regeneration failure and the potential importance of human disturbance in a subtropical forest. Applied Vegetation Science, 3(2), 223-232.

Wilson, J. R. U., Richardson, D. M., Rouget, M., Procheş, Ş., Amis, M. A., Henderson, L., \& Thuiller, W. (2007). Residence time and potential range: crucial considerations in modelling plant invasions. Diversity and Distributions, 13(1), 11-22. https://doi.org/10.1111/j.1366-9516.2006.00302.x.

Witkowski, E. T. F., \& Garner, R. D. (2008). Seed production, seed bank dynamics, resprouting and long-term response to clearing of the alien invasive Solanum mauritianum in a temperate to subtropical riparian ecosystem. South African Journal of Botany, 74(3), 476-484.
Zachariades, C., Muniappan, R., \& Strathie, L. W. (2002). Proceedings of the Fifth International Workshop on biological control and management of Chromolaena odorata, Durban, South Africa, 23-25 October 2000. Pretoria.

Ziółkowska, E., Ostapowicz, K., Radeloff, V. C., \& Kuemmerle, T. (2014). Effects of different matrix representations and connectivity measures on habitat network assessments. Landscape Ecology, 29(9), 1551-1570. https://doi.org/ 10.1007/s10980-014-0075-2.

\section{Submit your manuscript to a SpringerOpen ${ }^{\circ}$ journal and benefit from:}

- Convenient online submission

- Rigorous peer review

- Open access: articles freely available online

- High visibility within the field

- Retaining the copyright to your article

Submit your next manuscript at $\boldsymbol{\nabla}$ springeropen.com 